\title{
Water Vapor Permeability of Edible Films Based on Improved Cassava (Manihot esculenta Crantz) Native Starches
}

\author{
Adjouman YD ${ }^{1,2,3 *}$, Nindjin $C^{1,2}$, Tetchi FA' ${ }^{1}$, Dalcq AC ${ }^{3}$, Amani NG ${ }^{1}$, and Sindic $\mathbf{M}^{3}$ \\ ${ }^{1}$ Université Nangui Abrogoua, UFR des Sciences et Technologies des Aliments, Abidjan, Côte d'lvoire, West Africa \\ ${ }^{2}$ Centre Suisse de Recherches Scientifiques en Côte d'Ivoire, CSRS-Cl, Abidjan, Côte d'Ivoire, West Africa \\ ${ }^{3}$ Université de Liège, Gembloux Agro-Bio Tech, Gembloux, Belgique, Belgium
}

\begin{abstract}
Starch is used in the production of edible biodegradable packaging as an attractive alternative to synthetic polymers because it is a natural biopolymer of low cost and high availability. Many studies have been carried out on films based on cassava starch and the results show that these have good flexibility and low water vapor permeability. This present research was conducted to analyse the effect of glycerol, peanut oil and soybean lecithin on the water vapor permeability (WVP) of edible films based on improved cassava (Manihot esculenta Crantz) native starches from Côte d'Ivoire. The films were prepared using $4 \mathrm{~g}$ cassava starch, $25 \%$ and $30 \%$ glycerol (w/w), $5 \%$ and $10 \%$ peanut oil $(\mathrm{w} / \mathrm{w})$ and $0 \%$ to $5 \%$ soybean lecithin (w/w oil) in Petri dishes. The WVP of the films was determined at $25^{\circ} \mathrm{C}$ and $75 \%$ relative humidity. The moisture content of the films was determined in an oven at $105^{\circ} \mathrm{C}$ and the film thickness was determined manually using a micrometer. The resulting films were homogeneous, transparent and crack-free. WVP, moisture content and thickness of the films increased with increasing glycerol concentration. Increasing the concentrations of the peanut oil and soybean lecithin decreased the thickness and increased the moisture content of the films. The combination of glycerol and peanut oil increased the WVP of the films, whereas addition of soybean lecithin had no effect. The lowest WVP values were obtained using $25 \%$ glycerol, $5 \%$ peanut oil and $5 \%$ soybean lecithin. Starch obtained from improved cassava varieties cultivated in Côte d'Ivoire can be a potential ingredient in the production of food packaging.
\end{abstract}

Keywords: Cassava starch; Water vapor permeability; Emulsified films; Glycerol; Peanut oil; Soybean lecithin

Abbreviations: WVTR: Water Vapor Transmission Rate; WVP: Water Vapor Permeability; FIRCA: Interprofessional Fund for Agricultural Research and Council; W/W: Weight per Weight

\section{Introduction}

Increasing pressure from society and legislation to minimise synthetic non-degradable packaging has encouraged research directed towards the production of biodegradable alternatives prepared from natural biopolymers. Consequently, the literature contains a plethora of studies that aim to either improve the properties of materials already used or to use new materials to attempt to produce packages with similar properties to their synthetic counterparts. In particular, the development of biodegradable films and edible materials from ecofriendly biopolymers, products and by-products of agro-materials and renewable sources is growing due to an increased environmental awareness [1,2]. For edible films and coatings, the materials and additives in their formulations are restricted to food-grade compounds. Thus, the main component of these thin and flexible materials capable of forming a continuous matrix is a biopolymer [2]. Among the natural polymers, starch is considered one of the most promising materials due to its combination of low-cost, performance $[3,4]$, such as flexibility, transparency and thermoplasticity [5], and high natural abundance [6]. According to the European Starch Industry Association, the global starch market was valued at over USD 56 million in 2014 with an estimated production output of 76 million tonnes in the same year [7]. China and Brazil are the main contributors, with a total increase of $10 \%$ per year, while other countries have observed $1 \%-2 \%$ per annum [8]. Cassava (Manihot esculenta Crantz) roots are one of the most important sources of starch worldwide. The global cassava production in 2015 was estimated at 281.1 million tonnes (fresh root equivalent) with approximately $54 \%$ produced in Africa [9]. Cassava is the second major food crop after yam in Côte d'Ivoire, which produced an estimated 5.1 million tonnes of cassava in 2015 [9].
Edible films may be heterogeneous in nature, consisting of polysaccharides, proteins and lipids, or their combinations. This approach allows using the separate functional characteristics of each film-forming component to improve the film properties [1012]. For instance, gelatin has been incorporated into starch [13] and hydroxypropyl starch films [14]. More recently Acosta et al. [15] combined cassava starch, gelatin and fatty acid ester (E-471) to improve cassava starch film properties. Perazzo et al. [16] produced active packaging from cassava starch and an aqueous extract of green tea and palm oil extracts. In other studies, composite films have been prepared based on cassava starch and apple pectin with the addition of laurel oil and oleic acid [17] and cassava starch, peanut oil and sucrose [18]. Rodriguez et al. [19] found a synergistic behaviour (lower tensile strength, higher elongation and higher water vapour permeability, WVP) between glycerol (as plasticiser) and emulsifiers, such as Tween 20, Span 80 and soybean lecithin, in potato starch films. Finally, Dias et al. [20] used glycerol as the plasticiser in gelatin-based films containing Yucca schidigera extract and lecithin, respectively. They obtained solid, flexible films with low WVP and concluded that addition of other emulsifiers commonly associated with plasticisers typically used in the production of edible and biodegradable films should be explored.

In this context, this study aimed to analyse the effect of glycerol,

*Corresponding author: Adjouman YD, Université Nangui Abrogoua, UFR des Sciences et Technologies des Aliments, 02 B.P 801 Abidjan, Côte d'Ivoire, Tel: +225-08642119; E-mail: desyadjouman@gmail.com

Received February 20, 2017; Accepted March 13, 2017; Published March 20 2017

Citation: Adjouman YD, Nindjin C, Tetchi FA, Dalcq AC, Amani NG, et al (2017) Water Vapor Permeability of Edible Films Based on Improved Cassava (Manihot esculenta Crantz) Native Starches. J Food Process Technol 8: 665. doi: 10.4172/2157-7110.1000665

Copyright: (c) 2017 Adjouman YD, et al. This is an open-access article distributed under the terms of the Creative Commons Attribution License, which permits unrestricted use, distribution, and reproduction in any medium, provided the original author and source are credited. 
Citation: Adjouman YD, Nindjin C, Tetchi FA, Dalcq AC, Amani NG, et al. (2017) Water Vapor Permeability of Edible Films Based on Improved Cassava (Manihot esculenta Crantz) Native Starches. J Food Process Technol 8: 665. doi: 10.4172/2157-7110.1000665

peanut oil and soybean lecithin on the WVP of films based on improved cassava native starches produced in Côte d'Ivoire.

\section{Materials and Methods}

\section{Materials}

The native starch used was obtained by cold water extraction from cassava (M. esculenta Crantz) varieties Bocou 2, Yavo and TMS, belonging to the National Agricultural Research Centre in Côte d'Ivoire genotype collection. The cassava plant was harvested at maturity, 12 months after plantation. Glycerol (bidistilled, 99.5\% purity) and soybean lecithin were purchased from VWR Prolabo Chemicals (Leuven, Belgium). The CORA brand peanut oil used in this study was purchased at a supermarket in Belgium.

\section{Methods}

Film preparations and thickness measurements: The emulsified films were prepared in two steps. First, $4 \mathrm{~g}$ (w/w, starch) cassava starch was mixed with glycerol (1-1.2 g based on the starch weight) with twothirds of distilled water and the final mixture heated from $30^{\circ} \mathrm{C}$ to $75^{\circ} \mathrm{C}$ for $20 \mathrm{~min}$. Peanut oil (w/w, based on the starch weight), soybean lecithin (w/w based on the amount of added oil) and distilled water (a third of the total mixture) (Table 1) was also heated together for $20 \mathrm{~min}$ from $30^{\circ} \mathrm{C}$ to $75^{\circ} \mathrm{C}$. Both solutions were heated with constant stirring at $750 \mathrm{rpm} / \mathrm{min}$. Thereafter, the solution of peanut oil, soybean lecithin and distilled water was homogenised at $24000 \mathrm{rpm}$ for 2 min using an Ultra-Turrax T25 basic (IKA Werke, Staufen /Germany). Next, the homogenised solution was mixed with the starch and glycerol and then heated from $75^{\circ} \mathrm{C}$ to $95^{\circ} \mathrm{C}$ at $750 \mathrm{rpm}$ for $25 \mathrm{~min}$. A 20-g aliquot of the final solution obtained was cast on the surface of a Petri dish and oven-dried in a ventilated model (Memmert UF-110, Schwabach / Germany) at $35^{\circ} \mathrm{C}$ for $24 \mathrm{~h}$. The dried films were removed and stored at $55 \%$ moisture (saturated ammonium nitrate) in a desiccator at $25^{\circ} \mathrm{C}$ for $48 \mathrm{~h}$, before testing. Films with only starch and glycerol were prepared

\begin{tabular}{|c|c|c|c|c|}
\hline $\begin{array}{l}\text { Starch } \\
4 \%(g)\end{array}$ & $\begin{array}{c}\text { Oil } 5-10 \% \\
\text { (g/g starch } \\
\text { basis) }\end{array}$ & $\begin{array}{c}\text { Glycerol } 25 \% \text { and } \\
30 \% \\
\text { (g/g starch basis) }\end{array}$ & $\begin{array}{c}\text { Soy lecithin } 0 \% \\
\text { and } 5 \% \text { ( } \mathrm{mg} / \mathrm{g} \text { oil } \\
\text { incorporated) }\end{array}$ & $\begin{array}{l}\text { Potassium } \\
\text { sorbate }(0.2 \mathrm{~g})\end{array}$ \\
\hline \multirow{8}{*}{4.0} & 0.2 & 1.0 & \multirow{2}{*}{30.0} & \multirow{8}{*}{0.2} \\
\hline & 0.2 & 1.0 & & \\
\hline & 0.2 & 1.2 & \multirow{2}{*}{30.0} & \\
\hline & 0.2 & 1.2 & & \\
\hline & 0.4 & 1.0 & \multirow{2}{*}{60.0} & \\
\hline & 0.4 & 1.0 & & \\
\hline & 0.4 & 1.2 & \multirow{2}{*}{60.0} & \\
\hline & 0.4 & 1.2 & & \\
\hline
\end{tabular}

Table 1: Film formulations.
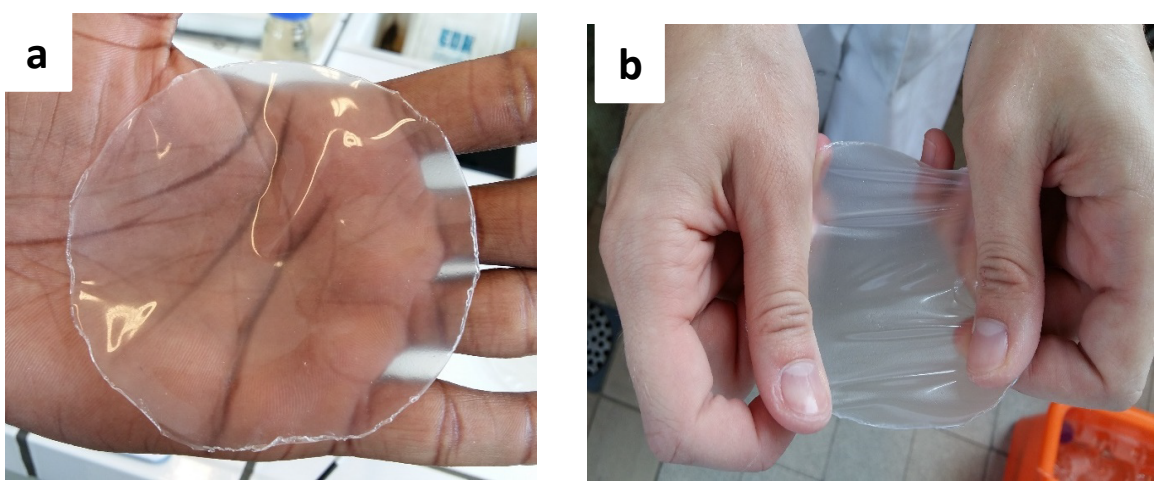

Figure 1: Cassava starch based emulsified film: a) Appearance of the film, b) Flexibility of the film by heating from $30^{\circ} \mathrm{C}$ to $95^{\circ} \mathrm{C}$ at $750 \mathrm{rpm} / \mathrm{min}$ for $45 \mathrm{~min}$ before a $20-\mathrm{g}$ aliquot was cast, dried and stored under the same conditions as the emulsified films. The thickness of all films was determined using a hand micrometer (NSK, Japan) at 10 random positions on the films. Three observations are available per variety and formulation.

Moisture content: The moisture content of the films was determined gravimetrically by oven drying at $105^{\circ} \mathrm{C}$ until constant weight (dry sample weight) [1]. The results were expressed as a percentage of the initial film weight, according to equation (1). At least triplicate analyses were performed per variety and formulation.

$$
\text { Humidity }(\%)=\frac{(\text { InitialWeight }-1)}{\text { FinalWeight }} \times 100
$$

WVP determination: The WVP of the films was conducted according to the ASTM method [21] with some modifications. Circular film samples were mounted and sealed on the open mouth of cylindrical cups containing $50 \mathrm{~g}$ of anhydrous calcium chloride $(0 \%$ relative humidity, $\mathrm{RH}$ ) to maintain an $\mathrm{RH}$ difference of $75 \%$ through the film. The assembly was placed in a desiccator at $25^{\circ} \mathrm{C}$ containing a saturated solution of sodium chloride ( $75 \% \mathrm{RH})$. After the steadystate conditions were reached $(2 \mathrm{~h})$, eight weight measurements were taken over $8 \mathrm{~h}$. Changes in the weight of the cups were recorded to the nearest $0.0001 \mathrm{~g}$ and plotted as a function of time. The slope of each line was calculated by linear regression $\left(r^{2}>0.99\right)$, and the water vapor transmission rate (WVTR) was calculated from the slope of the straight line $(\mathrm{g} / \mathrm{s})$ divided by the cell area $\left(\mathrm{m}^{2}\right)$. The exposed area was 0.00246 $\mathrm{m}^{2}$. After the permeation tests, the film thickness was measured and the WVP $\left(\mathrm{g} \mathrm{m}^{-1} \mathrm{~s}^{-1} \mathrm{~Pa}^{-1}\right)$ was calculated as follows:

$$
W V P=\left[W V T R / S\left(R_{1}-R_{2}\right) \times D\right]
$$

Where $S$ is the saturation vapor pressure of water $(\mathrm{Pa})$ at the test temperature $\left(25^{\circ} \mathrm{C}\right), R_{1}$ is the $\mathrm{RH}$ in the desiccator, $R_{2}$ is the $\mathrm{RH}$ in the permeation cell and $D$ is the film thickness (m). Duplicate analyses were performed per variety and formulation.

Statistical analysis: A two-way analysis of variance (ANOVA) was performed to study the effect of the cassava varieties and the film formulations on the continuous variables, namely WVP, thickness and moisture content (level of significance $=0.05$ ). The significance of the interaction between the cassava varieties and film formulations was studied. The normality of the distribution of the observations and the homoscedasticity were checked a posteriori, on the residuals of the model. The Newman-Keuls and the contrasts methods were used for the comparison of the means, which were significantly different. The statistical analysis was performed using SAS software version 9.4 . 
Citation: Adjouman YD, Nindjin C, Tetchi FA, Dalcq AC, Amani NG, et al. (2017) Water Vapor Permeability of Edible Films Based on Improved Cassava (Manihot esculenta Crantz) Native Starches. J Food Process Technol 8: 665. doi: 10.4172/2157-7110.1000665

Page 3 of 6

\section{Results and Discussion}

Films obtained with the various improved cassava starch varieties were homogeneous, transparent and did not exhibit any cracks (Figure 1a). Furthermore, they were flexible and tenable in the hand, as shown in Figure 1b. Films prepared from 30\% glycerol and 10\% oil, with or without soybean lecithin, were very sticky and often difficult to handle. Films produced with only glycerol (30\%) in the formulations also presented these behaviours.

The Table 2 shows the thickness of the cassava starch-based films including $25 \%$ or $30 \%$ glycerol, $0 \%, 5 \%$ or $10 \%$ peanut oil and $0 \%$ or $5 \%$ soybean lecithin. For the films containing only glycerol in the formulations, the highest thicknesses were obtained with $30 \%$ glycerol $(P<0.001)$. The thickness increased significantly as the glycerol concentration was increased, in agreement with previous authors [2226]. For films containing $25 \%$ glycerol, increasing the oil concentration from 5 to $10 \%$, significantly increased the film thickness for the variety TMS $(P<0.001)$. In contrast, varieties Yavo and Bocou 2 did not show this trend $(P>0.05)$. Adding $5 \%$ soybean lecithin and 5 or $10 \%$ oil to the starch slurry containing $25 \%$ glycerol, significantly increased the thickness of the resulting films made from Bocou 2 and Yavo varieties $(P<0.001)$. At $30 \%$ glycerol concentration, increasing the oil concentration from 5 to $10 \%$ significantly decreased the film thickness made from Bocou 2 and Yavo varieties $(P<0.001)$, which contrasted with the observations for $25 \%$ glycerol. At $30 \%$ glycerol concentration, the addition of soybean lecithin in the presence of oil, significantly

\begin{tabular}{|c|c|c|c|c|c|}
\hline \multicolumn{3}{|c|}{ Film formulations } & \multicolumn{3}{c|}{ Film thickness $(\mu \mathrm{m})$} \\
\hline $\begin{array}{c}\text { Glycerol } \\
(\%)\end{array}$ & $\begin{array}{c}\text { Oil } \\
(\%)\end{array}$ & $\begin{array}{c}\text { Soy lecithin } \\
(\%)\end{array}$ & Bocou 2 & Yavo & TMS \\
\hline 25 & 0 & 0 & $79.5 \pm 0.50^{\mathrm{a}} \mathrm{E}$ & $82.0 \pm 1.00^{\mathrm{a}} \mathrm{D}$ & $83.5 \pm 1.80^{\mathrm{a}} \mathrm{BC}$ \\
\hline 30 & 0 & 0 & $98.5 \pm 0.50 \mathrm{~A}$ & $92.5 \pm 1.00 \mathrm{~A}$ & $91.7 \pm 0.75 \mathrm{~A}$ \\
\hline 25 & 5 & 0 & $92.0 \pm 2.00 \mathrm{BC}$ & $85.7 \pm 0.25 \mathrm{C}$ & $82.5 \pm 2.00 \mathrm{BC}$ \\
\hline 25 & 5 & 5 & $86.5 \pm 3.50$ & $88.7 \pm 0.25 \mathrm{BC}$ & $78.5 \pm 1.00 \mathrm{D}$ \\
\hline 25 & 10 & 0 & $79.0 \pm 0.50 \mathrm{E}$ & $75.4 \pm 0.50 \mathrm{E}$ & $85.0 \pm 1.00 \mathrm{~B}$ \\
\hline 25 & 10 & 5 & $87.3 \pm 1.25$ & $80.5 \pm 0.50 \mathrm{D}$ & $79.7 \pm 1.25 \mathrm{CD}$ \\
\hline 30 & 5 & 0 & $97.5 \pm 1.50 \mathrm{AB}$ & $86.5 \pm 0.50 \mathrm{C}$ & $84.5 \pm 0.50 \mathrm{~B}$ \\
\hline 30 & 5 & 5 & $95.5 \pm 4.50 \mathrm{AB}$ & $91.0 \pm 2.00 \mathrm{AB}$ & $73.0 \pm 0.50 \mathrm{E}$ \\
\hline 30 & 10 & 0 & $80.2 \pm 0.75 \mathrm{E}$ & $81.5 \pm 1.50 \mathrm{D}$ & $76.0 \pm 1.00 \mathrm{DE}$ \\
\hline 30 & 10 & 5 & $83.0 \pm 0.50 \mathrm{DE}$ & $82.0 \pm 2.00 \mathrm{D}$ & $85.0 \pm 2.00 \mathrm{~B}$ \\
\hline
\end{tabular}

Lowercase superscript "a" indicates the standard deviations of three measurements.

Values assigned different uppercase letters in columns are significantly different.

Table 2: Thickness of films based on improved cassava starch varieties.

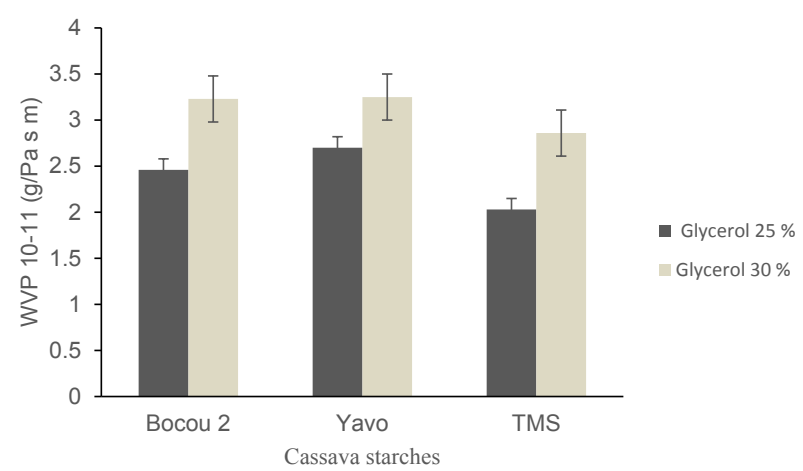

Figure 2: Effect of glycerol content on water vapor permeability of cassava starch-based films.

\begin{tabular}{|c|c|c|c|c|c|}
\hline \multicolumn{3}{|c|}{ Film formulations } & \multicolumn{3}{c|}{ Moisture content (\%) } \\
\hline $\begin{array}{c}\text { Glycerol } \\
(\%)\end{array}$ & $\begin{array}{c}\text { Oil } \\
(\%)\end{array}$ & $\begin{array}{c}\text { Soy } \\
\text { lecithin (\%) }\end{array}$ & Bocou 2 & Yavo & TMS \\
\hline 25 & 0 & 0 & $16.57 \pm 0.06^{\mathrm{a}} \mathrm{F}$ & $17.15 \pm 0.47^{\mathrm{a}} \mathrm{B}$ & $16.35 \pm 0.11^{\mathrm{a}} \mathrm{DE}$ \\
\hline 30 & 0 & 0 & $21.83 \pm 0.01 \mathrm{C}$ & $21.53 \pm 0.37 \mathrm{~A}$ & $21.92 \pm 0.03 \mathrm{~A}$ \\
\hline 25 & 5 & 0 & $11.79 \pm 0.08 \mathrm{~J}$ & $10.95 \pm 0.07 \mathrm{D}$ & $11.13 \pm 0.03 \mathrm{H}$ \\
\hline 25 & 5 & 5 & $12.78 \pm 0.02 \mathrm{I}$ & $11.74 \pm 0.12 \mathrm{D}$ & $12.26 \pm 0.03 \mathrm{G}$ \\
\hline 25 & 10 & 0 & $18.06 \pm 0.02 \mathrm{E}$ & $17.39 \pm 1.12 \mathrm{~B}$ & $17.07 \pm 0.65 \mathrm{D}$ \\
\hline 25 & 10 & 5 & $18.73 \pm 0.05 \mathrm{D}$ & $17.58 \pm 0.13 \mathrm{~B}$ & $18.28 \pm 0.12 \mathrm{C}$ \\
\hline 30 & 5 & 0 & $15.71 \pm 0.1 \mathrm{H}$ & $13.88 \pm 0.03 \mathrm{C}$ & $14.86 \pm 0.12 \mathrm{~F}$ \\
\hline 30 & 5 & 5 & $16.38 \pm 0.05 \mathrm{~F}$ & $14.83 \pm 0.05 \mathrm{C}$ & $15.75 \pm 0.04 \mathrm{E}$ \\
\hline 30 & 10 & 0 & $23.99 \pm 0.03 \mathrm{~B}$ & $20.49 \pm 0.12 \mathrm{~A}$ & $20.98 \pm 0.4 \mathrm{~B}$ \\
\hline 30 & 10 & 5 & $24.34 \pm 0.04 \mathrm{~A}$ & $20.87 \pm 0.03 \mathrm{~A}$ & $21.03 \pm 0.24 \mathrm{~B}$ \\
\hline
\end{tabular}

Lowercase superscript "a" indicates the standard deviations of three measurements.

Values assigned different uppercase letters are significantly different.

Table 3: Moisture content of films based on improved cassava starch varieties.

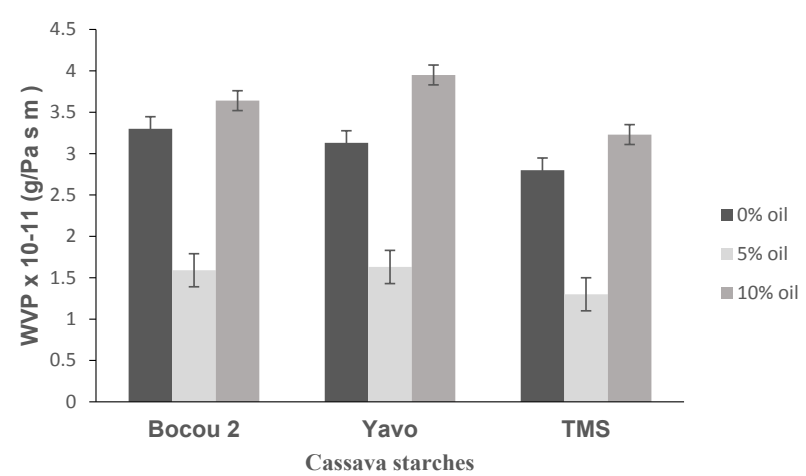

Figure 3: Effect of oil content on water vapor permeability of cassava starchbased films.

increased film thickness of Yavo variety $(P<0.01)$ but not with TMS and Bocou 2 varieties $(P>0.05)$. These results disagreed with those of Nindjin et al. [18] and Nilsuwan et al. [27], which demonstrated that a combination of oil and plasticiser increased the film thickness. The highest film thickness were $98.5 \mu \mathrm{m}, 92.5 \mu \mathrm{m}$ and $91.7 \mu \mathrm{m}$, respectively for varieties Bocou 2, Yavo and TMS with $30 \%$ glycerol formulation lacking of peanut oil and soybean lecithin (Figure 2).

The glycerol concentration had a significant effect $(P<0.001)$ on moisture content of the films without oil and soybean lecithin in the formulations. Moisture content increased significantly with increasing glycerol concentration, irrespective of the cassava variety (Table 3 ). This result concurred with Alves et al. [28] and Lopez et al. [5], which observed an increase in moisture content of the starch-based films following an increase in the concentration of glycerol. This phenomenon is linked to the hydrophilic properties of glycerol. Adding $5 \%$ oil to the formulations significantly decreased the moisture content of the films $(P<0.001)$ but increasing the oil concentration to $10 \%$ significantly increased the moisture content $(P<0.001)$, irrespective of the cassava starch variety. Addition of soybean lecithin significantly influenced the moisture content of the films $(P<0.001)$. Some lipids have a low affinity with the ingredients in which they are used to produce films. In our study, the affinity was not investigated. Nindjin et al. [18] reported a less affinity between vegetable oil and sucrose, when studying the effects of these components on the properties of cassava starch-based edible films. Thus, the increase in moisture content on addition of soybean lecithin and its consequent interaction with glycerol could be explained by the hydrophilicity of lecithin. Rodriguez et al. [19] investigated 
the combined effect of plasticisers and emulsifiers on the properties of starch-based edible films and found that films with glycerol and a high surfactant concentration behaved similar to films with a relatively larger plasticiser content. In the current study, the lowest moisture contents were found for the formulations containing $25 \%$ glycerol, $5 \%$ oil without lecithin (Figure 3). The values were of $10.95 \%, 11.13 \%$ and $11.79 \%$ for Yavo, TMS and Bocou 2, respectively (Table 3).

Using soybean lecithin as emulsifier whatever the presence or absence of glycerol, significantly influenced the WVP of the films made from starch of the variety Yavo $(p<0.05)$ but not those from the varieties Bocou 2 and TMS ( $p>0.05)$. The WVP of the starch-based films made from the three improved cassava varieties with glycerol at 25 and $30 \%$ concentrations, showed a significant difference (Table 4). The WVP values obtained for Bocou 2, Yavo and TMS increased from $2.51 \times 10^{-11}$ $\mathrm{g} / \mathrm{m} \mathrm{s} \mathrm{Pa}, 2.43 \times 10^{-11} \mathrm{~g} / \mathrm{m} \mathrm{s} \mathrm{Pa}$ and $2.06 \times 10^{-11} \mathrm{~g} / \mathrm{m} \mathrm{s}$ Pa to $4.09 \times 10^{-11}$ $\mathrm{g} / \mathrm{m} \mathrm{s} \mathrm{Pa}, 3.83 \times 10^{-11} \mathrm{~g} / \mathrm{m} \mathrm{s} \mathrm{Pa}$ and $3.55 \times 10^{-11} \mathrm{~g} / \mathrm{m} \mathrm{s} \mathrm{Pa}$, at $25 \%$ and $30 \%$ glycerol, respectively. Similarly, many previous authors have also observed an increase in WVP with an increase in glycerol content of starch-based films [22,28-33]. This phenomenon has been explained by a decrease in intermolecular forces between polymer chains as the plasticiser concentration is increased, thus, increasing the free volume and movement of molecular chains [34], which promotes the dissemination of water molecules through the film. Park and Chinnan [35] explained the effect as a result of swelling of the hydrophilic matrix due to different structural changes in films with different thicknesses. For starch films plasticised with $15 \%$ to $45 \%$ glycerol, Sanyang et al. [30] also found that increasing the glycerol concentration increased the WVP, with the lowest concentration of glycerol corresponding to the lowest values of WVP. These authors attributed this behaviour to the strong interaction of starch molecules, which dominate the matrix at the lowest plasticiser concentrations, leading to a dense network of starch and a more compact structure. Conversely, the increase in plasticiser concentration promotes mobility and flexibility of the starch chains due to the structural modification of the molecular starch-starch interactions in a loose network. Therefore, the matrices become less dense and the WVP of the film increases.

The main function of food packaging is often to avoid or at least reduce the moisture transfer between the food and the surrounding atmosphere, or between two components of a heterogeneous food product, thus, the WVP of the film should be as low as possible [36]. In the current work, the oil was added to obtain emulsified films with

\begin{tabular}{|c|c|c|c|c|c|}
\hline \multicolumn{2}{|c|}{ Film formulations } & \multicolumn{3}{c|}{ WVP $\times 10^{-11}(\mathbf{g} / \mathrm{m}$ s Pa) } \\
\hline $\begin{array}{c}\text { Glycerol } \\
(\%)\end{array}$ & $\begin{array}{c}\text { Oil } \\
(\%)\end{array}$ & $\begin{array}{c}\text { Soy } \\
\text { lecithin } \\
(\%)\end{array}$ & Bocou 2 & Yavo & TMS \\
\hline 25 & 0 & 0 & $2.51 \pm 0.12^{\mathrm{a}} \mathrm{B}$ & $2.43 \pm 0.105^{\mathrm{a}} \mathrm{BC}$ & $2.06 \pm 0.005^{\mathrm{a}} \mathrm{BC}$ \\
\hline 30 & 0 & 0 & $4.09 \pm 0.235 \mathrm{~A}$ & $3.83 \pm 0.005 \mathrm{~A}$ & $3.55 \pm 0.05 \mathrm{~A}$ \\
\hline 25 & 5 & 0 & $1.42 \pm 0.05 \mathrm{C}$ & $1.65 \pm 0.015 \mathrm{CD}$ & $1.19 \pm 0.11 \mathrm{D}$ \\
\hline 25 & 5 & 5 & $1.4 \pm 0.265 \mathrm{C}$ & $1.12 \pm 0.06 \mathrm{D}$ & $1.06 \pm 0.106 \mathrm{D}$ \\
\hline 25 & 10 & 0 & $3.45 \pm 0.09 \mathrm{~A}$ & $3.76 \pm 0.06 \mathrm{~A}$ & $2.98 \pm 0.035 \mathrm{~A}$ \\
\hline 25 & 10 & 5 & $3.48 \pm 0.06 \mathrm{~A}$ & $3.31 \pm 0.025 \mathrm{AB}$ & $2.82 \pm 0.505 \mathrm{AB}$ \\
\hline 30 & 5 & 0 & $1.82 \pm 0.005 \mathrm{BC}$ & $1.6 \pm 0.05 \mathrm{CD}$ & $1.48 \pm 0.115 \mathrm{CD}$ \\
\hline 30 & 5 & 5 & $1.74 \pm 0.08 \mathrm{C}$ & $2.18 \pm 0.01 \mathrm{C}$ & $1.47 \pm 0.025 \mathrm{CD}$ \\
\hline 30 & 10 & 0 & $3.67 \pm 0.025 \mathrm{~A}$ & $4.32 \pm 0.06 \mathrm{~A}$ & $3.59 \pm 0.1 \mathrm{~A}$ \\
\hline 30 & 10 & 5 & $3.96 \pm 0.005 \mathrm{~A}$ & $4.16 \pm 0.025 \mathrm{~A}$ & $3.53 \pm 0.185 \mathrm{~A}$ \\
\hline
\end{tabular}

Lowercase superscript "a" indicates the standard deviations of three measurements.

Values assigned different uppercase letters are significantly different.

Table 4: Water vapour permeability of films based on improved cassava starch varieties.

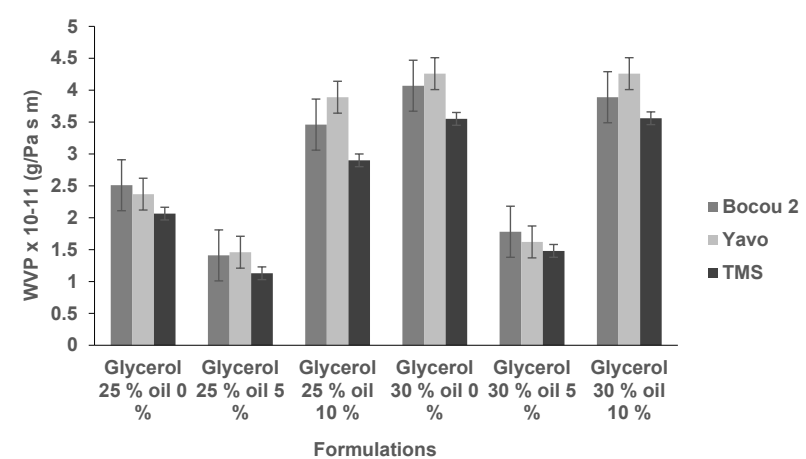

Figure 4: Combined effect of glycerol and oil contents on water vapor permeability of cassava starch-based films.

decreased WVP based on improved cassava starch. Accordingly, a significant decrease $(P<0.001)$ was verified. Adding $5 \%$ oil decreased the WVP compared to combinations in which the oil was not added but the opposite effect was produced when $10 \%$ oil was incorporated $(P<0.001)$. These results concur with those of Garcia et al. [37] for emulsified starch films containing corn and sunflower oil. A possible explanation for the increase in WVP of the emulsified film at $10 \%$ oil may be due to the oil (peanut) used. Both peanut and whole sunflower oil are rich in unsaturated fatty acids, such as oleic acid and linoleic acid. Compared to saturated fatty acids, unsaturated fatty acids are less effective at improving WVP because they are more polar $[38,39]$. The presence of one or more unsaturated bonds decreases the melting point of the lipid compound, which may explain the increase in WVP of the film because diffusion is 1000 times faster in liquids than in solids. Moreover, Gontard et al. [40] observed that due to its double bond, oleic acid has a degree of mobility, reducing the density of the macromolecular network and, thus, the effectiveness of the water. Moreover, increasing the number of carbon atoms (14 to 18), of water alcohols and fatty acids, improved the barrier effectiveness as the non-polar part of the molecule increases, reducing the solubility and, therefore, the transfer of water molecules through the film [41].

The combination between glycerol and oil was shown significant $(\mathrm{P}<0.001)$. At $5 \%$ oil concentration, an increase in the glycerol concentration induced a significant increase in the WVP of all films, irrespective of the cassava starch variety studied $(P=0.05)$. The same trend was observed at $10 \%$ oil concentration, except with the starch variety Yavo. Likewise, Nilsuwan et al. [27] demonstrated that at a constant concentration of palm oil, increasing the glycerol concentration $(0 \%, 10 \%, 20 \%$ and $30 \%)$ increased the WVP of fish skin gelatin films. However, in the current study, the main purpose of adding glycerol, oil and lecithin in the formulations was to provide the lowest possible WVP. The results showed that the interaction between $25 \%$ glycerol and $5 \%$ oil gave the lowest WVP values of $1.4 \times 10^{-11}, 1.12$ $\times 10^{-11}$ and $1.06 \times 10^{-11} \mathrm{~g} / \mathrm{m} \mathrm{s}$ Pa for varieties Bocou 2, Yavo and TMS, respectively. WVP is improved when the size of lipidic droplets present in the emulsified films is reduced and these fatty inclusions are more dispersed [42]. Soybean lecithin was used for this purpose in the current study but either the presence or absence of lecithin not significantly improved the WVP for the varieties Bocou 2 and TMS $(P>0.05)$. The reductions in the WVP values of the films after addition of lecithin were minimal. This was not the case for the Yavo variety where the presence of lecithin significantly decreased WVP. The addition of an emulsifier may also have diminished the humidity content of the films, due to the interaction of hydrogen bridges between the hydrocolloid and the polar groups of the emulsifier, thus reducing the number of 
Citation: Adjouman YD, Nindjin C, Tetchi FA, Dalcq AC, Amani NG, et al. (2017) Water Vapor Permeability of Edible Films Based on Improved Cassava (Manihot esculenta Crantz) Native Starches. J Food Process Technol 8: 665. doi: 10.4172/2157-7110.1000665

polar groups available to interact with the water molecules [43]. This may be the case with the Yavo variety where WVP has experienced a significant decrease (Figure 4).

The WVP values of the films formulated with $25 \%$ glycerol, $5 \%$ peanut oil and $5 \%$ soybean lecithin $\left(1.4 \times 10^{-11} \mathrm{~g} / \mathrm{m} \mathrm{s} \mathrm{Pa}, 1.12 \times 10^{-11} \mathrm{~g} / \mathrm{m}\right.$ $\mathrm{s} \mathrm{Pa}$ and $1.06 \times 10^{-11} \mathrm{~g} / \mathrm{m} \mathrm{s} \mathrm{Pa}$, respectively, for varieties Bocou 2, Yavo and TMS) are lower than those of certain biodegradable plasticised films, such as wheat gluten with glycerol $\left(7 \times 10^{-10} \mathrm{~g} / \mathrm{m}^{-1} \mathrm{~s}^{-1} \mathrm{~Pa}^{-1}\right)[44]$, corn starch plasticised with sorbitol $\left(1.75 \times 10^{-10} \mathrm{~g} / \mathrm{m} \mathrm{s} \mathrm{Pa}\right)[37]$ and corn zein plasticised with glycerol $\left(8.9 \times 10^{-10} \mathrm{~g} / \mathrm{m} \mathrm{s} \mathrm{Pa}\right)$ [45]. The values are also lower than some synthetic films, such as cellophane $\left(8.4 \times 10^{-10}\right.$ $\mathrm{g} / \mathrm{m} \mathrm{s} \mathrm{Pa})[46]$, but higher than low-density polyethylene $\left(9.14 \times 10^{-13} \mathrm{~g} /\right.$ $\mathrm{m} \mathrm{s} \mathrm{Pa})$ and high-density polyethylene $\left(2.31 \times 10^{-13} \mathrm{~g} / \mathrm{m} \mathrm{s} \mathrm{Pa}\right)$ [47]. The values are also low compared to certain emulsified films, for example, hydroxypropyl méthylcellulose with plasticiser and oil $\left(1.90 \times 10^{-11} \mathrm{~g} / \mathrm{m}\right.$ s Pa) [41], cassava starch and $15 \%$ glycerol with hydrogenated vegetable oil $\left(2.94 \times 10^{-11} \mathrm{~g} / \mathrm{m} \mathrm{s} \mathrm{Pa}\right)$ and agar, $15 \%$ glycerol and hydrogenated vegetable oil $\left(1.44 \times 10^{-11} \mathrm{~g} / \mathrm{m} \mathrm{s} \mathrm{Pa}\right)$ [48] but higher than those observed by Nilsuwan et al. [27] $\left(7.92 \times 10^{-12} \mathrm{~g} / \mathrm{m} \mathrm{s} \mathrm{Pa}\right)$ for fish gelatin films with $30 \%$ glycerol and $75 \%$ palm oil.

\section{Conclusion}

This work was conducted to study the effect of incorporating glycerol, peanut oil and soybean lecithin on the WVP of films based on improved starch cassava varieties cultivated in Côte d'Ivoire and their potential for food packaging applications. The WVP, moisture content and film thickness increased with increasing glycerol concentration. In general, increasing the concentration of the peanut oil and soy lecithin decreased the thickness and increased the moisture content of the films. The combination of glycerol and peanut oil also increased the WVP of the films but the addition of soybean lecithin had no effect. The lowest WVP values were obtained using $25 \%$ glycerol, $5 \%$ peanut oil and 5\% soy lecithin. Improved cassava starch varieties cultivated in Côte d'Ivoire may be a potential ingredient in food packaging.

\section{Acknowledgment}

The authors would like to thank the Interprofessional Fund for Agricultural Research and Council (FIRCA) in Côte d'Ivoire, which has funded this study. They would also like to thank Marjorie Servais for establishing the film preparation method and Thomas Bertrand for all the technical support in the laboratory.

\section{References}

1. Versino F, Garcia MA (2014) Cassava (Manihot esculenta Crantz) starch films reinforced with natural fibrous filler. Industrial Crop Product 58: 305-314.

2. Lagos JB, Vicentini NM, Dos Santos RMC, Bittantea AMQB, Sobrala PJA (2015) Mechanical properties of cassava starch films as affected by different plasticizers and different relative humidity conditions. Int J Food Studie 4: 116-125.

3. Abdillahi H, Chabrat E, Rouilly A, Rigal L (2013) Influence of citric acid on thermoplastic wheat flour/poly (lactic acid) blends II. Barrier properties and water vapor sorption isotherms. Industrial Crop Product 50: 104-111.

4. Lopez OV, Garcia MA (2012) Starch films from a novel (Pachyrhizus ahipa) and conventional sources: Development and characterization. Material Sci Eng C 32: $1931-1940$

5. Lopez OV, Garcıa MA, Zaritzky NE (2008) Film forming capacity of chemically modified corn starches. Carbohydrate Polymer 73: 573-581.

6. Bonilla J, Atares L, Vargas M, Chiralt A (2013) Properties of wheat starch filmforming dispersions and films as affected by chitosan addition. J Food Eng 114: 303-312.

7. GMI (Global Market Insights) (2016) Biodegradable superabsorbent materials market size by product, by application, industry analysis report, regional outlook, application potential, price trend, competitive market share and forecast, 20162023. Global Market Insights, USA.
8. Avérous LR, Halley PJ (2014) Starch polymers: From the field to industria products.

9. FAO (2016) Food outlook biannual report on global food markets. Food and Agriculture Organisation of the United Nations.

10. Müller CMO, Laurindo JB, Yamashita F (2009) Effect of cellulose fibers addition on the mechanical properties and water vapor barrier of starch-based films. Food Hydrocolloid 23: 1328-1333.

11. Bilbao-Sáinz C, Avena-Bustillos RJ, Wood DF, Williams TG, Mc Hugh TH (2010) Composite edible films based on hydroxypropyl methylcellulose reinforced with microcrystalline cellulose nanoparticles. J Agricultural Food Chem 58: 3753-3760.

12. Kester JJ, Fennema OR (1986) Edible films and coatings: A review. Food Technol 40: 47-59.

13. Arvanitoyannis I, Kolokuris I, Nakayama A, Yamamoto N, Aiba SI (1997) Physico-chemical studies of chitosan-poly (vinyl alcohol) blends plasticized with sorbitol and sucrose. Carbohydrate Polymer 34: 9-19.

14. Arvanitoyannis I, Nakayama A, Aiba S (1998) Edible films made from hydroxypropyl starch and gelatin and plasticized by polyols and water Carbohydrate Polymer 36: 105-119.

15. Acosta S, Jiménez A, Chiralt A, Martinez CG, Cháfer M (2013) Mechanical barrier and microstructural properties of films based on cassava starch gelatin blends: Effect of aging and lipid addition. Inside Food Symposium, Leuven, Belgium.

16. Perazzo KKNCL, De Vasconcelos ACC, Dos Santos JCP, De Jesus Assis D, Souza CO, et al. (2014) Properties and antioxidant action of actives cassava starch films incorporated with green tea and palm oil extracts. PLoS One 9 : e105199.

17. Taqi A, Mutihac L, Stamatin I (2014) Physical and barrier properties of apple pectin/cassava starch composite films incorporating Laurus nobilis I. Oil and oleic acid. J Food Process Preserv 38: 1982-1993.

18. Nindjin C, Beyrer M, Amani GN (2015) Effects of sucrose and vegetable oil on properties of native cassava (Manihot esculenta Crantz) starch-based edible films. Africa J Food Agri Nutri Develop 15: 9905-9921.

19. 19. Rodrıguez M, Oses J, Ziani K, Mate Jl (2006) Combined effect of plasticizers and surfactants on the physical properties of starch based edible films. Food Res Int 39: 840-846.

20. Dias TP, Grosso CRF, Andreuccetti C, De Carvalho RA, Galicia-García T, et al. (2013) Effect of the addition of soy lecithin and Yucca schidigera extract on the properties of gelatin and glycerol based biodegradable films. Polímeros 23: $339-345$

21. ASTM (1995) Standard test methods for water vapor transmission of material Annual book of ASTM, American Society for Testing and Materials, Philadelphia.

22. Belibi PC (2014) Development and characterization of biofilms based on cassava starch reinforced by bi and tri-dimensional mineral fillers. Université de Haute Alsace, Mulhouse, France.

23. Banker GS (1966) Film coating, theory and practice. J Pharma Sci 55: 81-89.

24. Swartzberg HG (1986) Modelling of gas vapor transport through hydrophilic films. Food Packag Preserv 11: 115-135.

25. Hagenmaier RD, Shaw PH (1990) Moisture permeability of edible films made with fatty acid and hydroxypropyl methylcellulose. J Agri Food Chem 38: 1799-1803.

26. Mc Hugh TH, Avena-Bustillos R, Krochta JM (1993) Hydrophilic edible films: modified procedure for water vapor permeability and explanation of thickness effects. J Food Sci 58: 899-903.

27. Nilsuwan K, Benjakul S, Prodpran T (2016) Influence of palm oil and glycerol on properties of fish skin gelatin-based films. J Food Sci Technol 53: 2715-2724.

28. Alves VD, Mali S, Beléia A, Grossmann MVE (2007) Effect of glycerol and amylose enrichment on cassava starch film properties. J Food Eng 78: 941-946.

29. Talja RA, Helen H, Roos YH, Jouppila K (2007) Effect of various polyols and polyol contents on physical and mechanical properties of potato starch-based films. Carbohydrate Polymer 67: 288-295.

30. Sanyang ML, Sapuan SM, Jawaid M, Ishak MR, Sahari J (2015) Effect of 
Citation: Adjouman YD, Nindjin C, Tetchi FA, Dalcq AC, Amani NG, et al. (2017) Water Vapor Permeability of Edible Films Based on Improved Cassava (Manihot esculenta Crantz) Native Starches. J Food Process Technol 8: 665. doi: 10.4172/2157-7110.1000665

plasticizer type and concentration on tensile, thermal and barrier properties of biodegradable films based on sugar palm (Arenga pinnata) starch. Polymer 7: 1106-1124.

31. Chen CH, Lai LS (2008) Mechanical and water vapor barrier properties of tapioca starch/decolorized hsian-tsao leaf gum films in the presence of plasticizer. Food Hydrocolloid 22: 1584-1595.

32. Chillo S, Flores S, Mastromatteo M, Conte A, Gerschenson L, et al. (2008) Influence of glycerol and chitosan on tapioca starch-based edible film properties. J Food Eng 88: 159-168.

33. Mali S, Grossmann MVE, Garcıa MA, Martino MN, Zaritzky NE (2004) Barrier, mechanical and optical properties of plasticized yam starch films. Carbohydrate Polymer 56: 129-135.

34. Sothornvit R, Krochta JM (2000) Water vapor permeability and solubility of films from hydrolyzed whey protein. J Food Sci 65: 700-703.

35. Park HJ, Chinnan MS (1995) Gas and water vapor barrier properties of edible films from protein and cellulosic materials. J Food Eng 25: 497-507.

36. Gontard N, Guilbert S, Cuq JL (1992) Edible wheat gluten films: influence of the main process variables on film properties using response surface methodology. J Food Sci 57: 190-195.

37. Garcıa MA, Martino MN, Zaritzky NE (2000) Lipid addition to improve barrier properties of edible starch-based films and coatings. J Food Sci 65: 941-947.

38. Koelsch CM, Labuza TP (1992) Functional, physical and morphological properties of methylcellulose and fatty acid-based edible barriers. J Food Sci Technol 54: 1383-1389

39. Péroval C, Debeaufort F, Despré D, Voilley A (2002) Edible Arabinoxylan-based films: Effects of lipid type on water vapor permeability, film structure, and other physical characteristics. J Agri Food Chem 50: 3977-3983.

40. Gontard N, Duchez C, Cuq JL, Guilbert S (1994) Edible composite films of wheat gluten and lipids: water vapor permeability and other physical properties. Int J Food Sci Technol 29: 39-50.

41. Mc Hugh TH, Aujard JF, Krochta JM (1994) Plasticized whey protein edible films: Water vapor permeability properties. J Food Sci 59: 416-419.

42. Debeaufort F, Voilley A (1995) Effect of surfactants and drying rate on barrier properties of emulsified edible films. Int J Food Sci Technol 30: 183-190.

43. Villalobos R, Hernández-Munoz P, Chiralt A (2006) Effect of surfactants on water sorption and barrier properties of hydroxypropyl methylcellulose films. Food Hydrocolloid 20: 502-509.

44. Gennadios A, Weller CL, Gooding CH (1994) Measurements errors in water vapor permeability of highly permeable, hydrophilic edible films. J Food Eng 21: 395-409.

45. Aydt TP, Weller CL, Testin RF (1991) Mechanical and barrier properties of edible corn and wheat protein films. Transaction ASAE 34: 207-211.

46. Shellhammer TH, Krochta JM (1997) Whey protein emulsion film performance as affected by lipid type amount. J Food Sci 62: 390-394

47. Smith SA (1986) Polyethylene, low density. The Wiley encyclopaedia of packaging technology, Wiley, NY, USA.

48. Thea DP, Debeaufort F, Voilley A, Luu D (2009) Influence of hydrocolloid nature on the structure and functional properties of emulsified edible films. Food Hydrocolloid 23: 691-699. 